\title{
The Role and Features of Analytical Journalism in Kazakh society in the Era of Social Media
}

\author{
Kaken Kamzin $^{1} \&$ Madiyar Saudbayev ${ }^{2}$ \\ ${ }^{1}$ Department of Periodic and Electronic Media, Al-Farabi Kazakh Natonal University, Almaty, Kazakhstan \\ ${ }^{2}$ Department of Mass Communication, Suleyman Demirel University, Kaskelen, Kazakhstan \\ Correspondence: Madiyar Saudbayev, Department of Mass Communication, Suleyman Demirel University, \\ Kaskelen, Kazakhstan. E-mail: saudbayev.m@sdu.edu.kz
}

Received: April 30, 2014 Accepted: June 6, 2014 Online Published: July 11, 2014

doi:10.5539/ass.v10n15p55 URL: http://dx.doi.org/10.5539/ass.v10n15p55

\begin{abstract}
In this essay, the authors discuss truth as the key quality of journalism and argue that analytical journalism is the way to reach the truth. They separate analytical journalism from news making and reporting, and argues that these require different types of expertise. They discusses several issues that should be addressed in order to improve the area of analytical journalism in Kazakhstan, which include improving the general professional level of journalistic education and the necessity for deeper knowledge in other areas, such as the economy, politics, and literature in order to be able to examine events fully. The analytical journalist, in the opinion of authors, should not only have good knowledge of the field and be able to analyze events professionally, but also be able independently and candidly to process the information.
\end{abstract}

Keywords: Analytical journalism, truth in journalism, Kazakhstani journalism, Aitys, Kazakhstan

\section{Introduction}

The overall scientific and technical revolution in almost every sphere of society including the rapid development of the information delivery process has had a deep impact not only on the changes in global terms but also on the metamorphoses in the terms of our own cultural mentality, our history vision and our world perception in particular. It is an undeniable fact that the unlimited information flow showered on the humanity in the 20-th century and proceeding its influence even in the 21 -st century gives an opportunity to attain any idea, any viewpoint, and any value and even contact any personality at a very fast time. Thus, one has nothing but to select the sort of information convenient for him/her own needs. Such changes in information medium have strongly affected the journalism sphere, which directly entwines with the circulation of information itself and have fostered the emergence of more means of communication.

As time passes by, the journalistic work is destined to become an instrument that operates on only the fait accompli; and TV and radio, the once most influential and gigantic means of information, to only broadcast the talk show programs. However trendy they might seem, such cases hinder the full discovery of the true evidences and realities in political field and social environment and lead to the deficiency of journalistic analytical products Particularly, with the emergence and rise of new media has the general value of the information spread among society depreciated. As a result, at the age of the total cultural transformation due to the diverse Internet technologies the journalism grounds of every nation are slowly becoming similar with each other and are getting deprived of the ethnical and national features. Such tendency is deeply analyzed in the study dedicated on different 31 country's journalism sphere «The global journalist in the twenty-first century a cross-national study of journalistic competencies» by Lars Willnat, David H. Weaver, and Jihyang Choi. (Willnat, Weaver, \& Choi, 2013).

In the present article, the issues of objective truths in Kazakh journalism and the criticizing role of "aitys" (national traditional model of analytical journalism in the Kazakh society) will be touched.

The works and articles of national and foreign authors related to our research have been studied. For instance, the Russian author Tertychnyi, A. explores the analytical journalism from the view of genre systems in periodical media, (Tertychnyi, 1998) whereas Beljakova, L. studies the analytical journalism relating it to the 
personal analytical thinking skills of a journalist. (Beljakova, 2013) In our research, we study the analytical journalism in the aspects of its ethnicity and nationality.

\section{Methods}

Content analysis was done on the basis of journalistic materials of 8 sites of social and political orientation, which is used for the selection of the following criteria: Table 1.

- Scale of site.- Considered only the online publication and TV programs of republican and international level.

- History of site.- Period of existence of the online publication had at least 1 year at the time of content analysis (March 2014).

- Format of site-- Proportional representation was provided purely electronic publications, as well as sites that have printed format.

- Stable operation of the site.- Sift the sites in which publication has irregular character.

- Popularity of the site.- With the help of resource management for Internet statistics CounterZero considered the level of popularity (number of visits) of online publications.

As a result of selection in the study sample consisted of the following sites:

Table 1.

\begin{tabular}{cccc}
\hline № & Web-sites & Site History & Site Format \\
\hline 1. & abai.kz & More than 3 years, & the Internet edition \\
2. & alashainasy.kz & More than 3 years & Website publication \\
3. & halyksozi.kz & From 2 to 3 years of publication & Website \\
4. & zhasalash.kz & More than 3 years & Website publication \\
5. & kazakhtv.kz & More than 3 years & TV channel web sites \\
6. & kaztrk.kz & More than 3 years & TV channel web sites \\
7. & ru.euronews.com & More than 3 years & TV channel web sites \\
8. & $31 . k z$ & More than 3 years & TV channel web sites \\
\hline
\end{tabular}

As the unit of analysis was taken publication and its quantitative and qualitative characteristics. Selection of publications produced by the step that was calculated for each site separately, depending on the volume and intensity of renovation materials of online resource.

Overall the sample of publications were 200 articles from 4 periodical mass-media and 400 television material from 4 TV channels.

Table 2. The designation of sites sample materials

\begin{tabular}{llc}
\hline & \multicolumn{1}{c}{ Web-sites } & Selected materials \\
\hline 1. & abai.kz & 50 \\
2. & alashainasy.kz & 50 \\
3. & halyksozi.kz & 50 \\
4. & zhasalash.kz & 50 \\
5. & kazakhtv.kz & 50 \\
6. & kaztrk.kz & 50 \\
7. & ru.euronews.com & 50 \\
8. & $31 . k z$ & 50 \\
Total & & 400 \\
\hline
\end{tabular}


Content analysis was carried out using a specially designed the coding sheet, which makes the appropriate characteristics of the material. Then held arithmetic calculation values in quantitative and percentage.

The main categories of analysis were:

(The analysis covered the publication, published in the period from January 2013 to March 2014.)

- Material Type

- Genre view publication

- Number of characters (without nature publication Letters)

- Key publications

- Number of views

- Subject

- Number of comments

- Subdivision

- Support material

- Protagonist

- Copyright

- The image of the protagonist

- Copyright material

\section{Results}

Internet publication, as shows the comparative analysis, largely specializes in articles, commentaries, while publishing, backed by printed version, increasingly turning to short news stories. Also must be noted that the sites of the first type often publish reports, scientific publications and literary works, and the second type of publishing - interview. Along with this, an increase in the amount of talk show is observed on TV. Table 3

Table 3. Genre, type of publication

\begin{tabular}{ccccc}
\hline \multirow{2}{*}{ Genre, type of publication } & General & \multicolumn{3}{c}{ Type of mass-media } \\
\cline { 3 - 5 } & & Internet-media & Sites of print media & TV channels \\
\hline News stories & $32,9 \%$ & $29,7 \%$ & $37,7 \%$ & $12,0 \%$ \\
Reportage & $2,2 \%$ & $2,7 \%$ & $1,4 \%$ & $16,1 \%$ \\
Interview & $8,1 \%$ & $6,2 \%$ & $11,0 \%$ & $6,2 \%$ \\
Article, comments & $44,4 \%$ & $47,3 \%$ & $39,9 \%$ & - \\
Review & $0,5 \%$ & - & $1,3 \%$ & $7,9 \%$ \\
Allocution, advertisement & $2,9 \%$ & $2,9 \%$ & $2,9 \%$ & $8,9 \%$ \\
Essay, sketch & $1,0 \%$ & $1,3 \%$ & $0,7 \%$ & $5,8 \%$ \\
Analytical, investigational materials & $1,0 \%$ & $0,3 \%$ & $2,1 \%$ & $9,0 \%$ \\
Critique & $0,3 \%$ & $0,5 \%$ & - & $2,2 \%$ \\
Feuilleton, pamphlet & $0,7 \%$ & $1,1 \%$ & $0,3 \%$ & - \\
Talk show, round table, discussions & $0,9 \%$ & $0,9 \%$ & $0,9 \%$ & $16,1 \%$ \\
Life reportage & - & - & - & $5,0 \%$ \\
Scientific publication & $1,8 \%$ & $2,9 \%$ & $0,3 \%$ & - \\
Literary works & $3,0 \%$ & $4,0 \%$ & $1,6 \%$ & $2,8 \%$ \\
Genre is difficult to determine & $0,2 \%$ & $0,4 \%$ & $0,1 \%$ & $8,0 \%$ \\
\hline
\end{tabular}

\section{Discussion and Decision}

\subsection{Nature and Role of Truth on Journalism}

Human beings are the satellite model of God, an innovational project which He sent to the planet. The chief intention of human beings therefore is to immerse themselves in information, understand the world by analyzing and observing the environment, and look at stories through different prisms, thereby fulfilling their mission on 
earth. For this reason, human nature is parallel to the nature of journalism. The very essence of journalists in what they write or broadcast is to fulfill this moral obligation - revealing the truth. Moreover, the fundamental duty of an individual is to unveil the truth. As a famous Kazakh philosopher Kunanbayev (1961) maintained, one cannot grasp the truth until he or she thinks through, analyzes and evaluates a piece of information thoroughly. By so doing, Kunanbayev (ibid) argues that uncovering the truth is a profound cognitive activity.

According to the Georgian philosopher Mamardashvili (1991), "an individual is not an object and does not hold a static position; he or she consists of fluid events and aggregate occurrences such as love, faith, honesty, thoughts, etc. With respect to this, Mamardashvili (1991) mentioned that Plato offered the interesting dictum: "a human being is neither of the notions that have been mentioned; they are human-symbols". By saying this, he is denoting people's tendency to seek truth and authenticity. In many aspects, truth is synonymous with journalism. What is true is not objectively translated to the audience because it is moderated by human beings, adam-pende, or the descendants of those who committed the original sin. Although, human beings cannot carry the responsibilities given by God, clashes of interest and misunderstandings in everyday life are initiated by human beings. Therefore the everlasting equilibrium principle calls individuals to search for truth. This has been proven by many scholars and thinkers, and, likewise, Kazakh journalism has always followed this wisdom.

\subsection{Kazakh Journalism and Modernity}

Having said that, why do Kazakhstani journalists, academics as well as practitioners appear to be disappointed with the ways in which journalism depicts the reality of life? There are several reasons for this, of course. First, practically experienced journalists lack the current scientific knowledge. Second, talent is hereditary so not everybody can master journalism well, and third, in the past, journalism attracted the crème de la crème and the elite, whereas nowadays everybody who desires to study journalism does not hesitate to become one. For these reasons, currently, there are many journalists who cannot and do not understand the social role of journalism. They treat journalism only as a source of income and the means to become well-known to the public. Moreover, some of them are not sufficiently qualified. Consequently, national journalism is unable to report the truth; its public reputation has decreased, and it cannot afford to be called the "fourth estate". It follows that those who teach journalism need to pay attention to the professional education of future journalists. Anyone who would like to study journalism can sign up to the institute for advanced studies at the faculty of journalism of the Al Farabi Kazakh National University which was opened with the purpose of modernizing national journalism. One thing to note is that modernization is not only a development in economy and technology; it embraces reshaping and the purification of the mind and soul by developing individuals scientifically, literarily and artistically as well as spiritually. Modernization deals with historical, current and possibly future developments. This practice of modernization should start with the faculty members and then move on to the students and thus will contribute to the modernization of national journalism.

\subsection{Analytical Journalism}

These shortcomings imply that Kazakh journalistic science has many more hurdles to overcome. Each area needs new ideas, fresh approaches and a sui generis path. Some of our professionals practicing journalism contend that mere acknowledgement of facts is not the only purposeful endeavor as journalists analyze and socially relate to information, communicate with it, and interpret it. In addition, the question arises, can one satisfy a diverse audience with just a retelling of the facts? Of course, it does not. In my opinion, analytical journalism, which satisfies human beings' quest for knowledge, remains the chief way of approaching reality. It was, is now, and it will be so in future. Only analytical journalism is capable of presenting the clear rationale of a story, its perspectives, and the implications for the world. Analytical journalists look for possibilities to untangle the story and try to examine how it has been presented. This forces readers to ponder and compare their own views with the writer's, and come to a conclusion. Analytical journalism requires more than merely looking for news on the internet and noting down contemplations arrived at whilst musing at the office desk. In order to become an experienced analytical journalist, one needs a lot of practice and real life experience. This reminds the gnoseological position of Immanuel Kant who contended that experience is the way human beings perceive the outside world and is how individuals communicate with the environment. In this way human beings, the subjects of knowledge, learn the world through experience, which, in turn, expands their cognition.

Along with analysis and examination, analytical journalism includes the element of research. This sets apart analytical journalism from news making and opinion-based journalism. This also proves that we need to preserve and develop our long practiced customs such as analytical aspects of journalism, text interpretations, and other methods of examining information. 
The noticeable skill of newsmakers and reporters at the cutting edge is to broadcasting news quickly and succinctly. They describe what has happened at a certain place, and are valued for their ability to discover what has happened faster than their opponents and report it back to the audience. For example, the way the Russian news programme Vesti reported the breaking news when the Israeli scientist Dan Shechtman won the Nobel Prize.

Analytical journalism, the one that follows behind, is the source of higher quality social broadcasting which aims at capturing the essence of what is happening and thus requires more than just reporting. In a number of foreign media, reporters are treated separately from analysts with the former required to search for facts and figures whereas the latter, who have specialized knowledge in areas such as economics, politics, the law, literature, culture, the arts, sports, are asked to analyze and interpret the event. Sometimes scientists or experienced journalists from an appropriate arena are invited to analyze the situation. The analysts benefit from delving beneath the surface and candidly considering the story. They look for latent connections between the episodes of a story; evaluate the reasons lying behind it and comment on the importance and the development of the story. Along with general analytical abilities, this requires a professional knowledge in the specific sphere in which he or she is involved.

\subsection{Analytical Journalism in Kazakhstan}

At the moment, Kazakhstani journalists face two main issues, having specialized training and their ability to analytically process information. First, the graduates of the faculty of journalism at the Al Farabi Kazakh National University are encouraged to study additional subjects such as economy, the law, and agriculture. For instance, there are journalists specializing in analyzing news in the sphere of ecology who hold masters degrees in geography. This helps them to deepen their knowledge in a specific area so they can interpret better the information. Second, in order to further the depth of analytical journalism in the country, we would like to stress several points that should be addressed by the journalists in Kazakhstan while analyzing data:

1. To analyze cause and effect connectivity in space and time

2. Find out how events affect individuals, groups, society, and the world

3. Spot the patterns emerging in analyzed events, and prognosticate possible outcomes

4. As a result of analytical examinations, advise on possible actions or consequences.

These forms of analyses lead journalism several steps closer to the equilibrium principle that truth grants. The equilibrium principle and analytics are intertwined in the history of the nation.

In Kazakhstan, analytical journalism has a long history, and well known professors in the area, such as Amandosov (1968) and Kozhakeev (2007) have provided an exhaustive account of analytical journalism in textbooks. Various folklore tales, epics, proverbs, folk songs, and aitys are part of the Kazakh national heritage and form sources of analytical broadcasting that were used widely prior to contemporary journalistic methods. For instance, the aitys is a poetical competition, a singsong, between two poets who improvise songs based on social events, stories and occasions of importance to local people.

\subsection{Journalistic Concepts of Aitys}

Regarding to the journalistic conceptions, Amandosov T., who conducted the first researches on Kazakh journalism, notes about the genres: "They are divided according to the content, type and style of materials" (Amandosov, 1978). A contemporary researcher, Khamzin, divides journalistic genres based on the theories of Amandosov's works:a) news genre, chronicle, information, expanded news, interview, report, reportage, special reportage, press questionnaires; b) analytic genres: report, commentary, article, letter, summary, discussion, review, memo c) artistic-literal genres, artistic-journalistic commentaries, essay, feature story, satirical article, pamphlet, guide sketch d) show: plays, observations, reality-shows, and others." (Khamzin, 2012) As Knight (2008) mentioned, poetry is often as plain-spoken as good journalism, and in general, poets strive for clar ity and precision, which are found in the newspaper.

However, although abovementioned works studied the theory of journalism in details, both researchers did not ever mention about aitys, and its aspects in relation to the information exchange, shaped for the centuries in the lifestyle of Kazakh people. In Kazakh society, aitys served talented people as an opportune ity to show their abilities and to be known as akhyns. Mainly, there is a strict rule for akhyn acts; if they lose their previous competition, they have to inform about it to others in the places where they perform the next time. (Saudbayev, 2014). Certainly, this is also delivered in poetic way during the performances. Because of the popularity of such competitions, some aitys works of good akhyns had been formed as ballads and legends in logical systematic way. According to Kazakh expert, (Barmankulov, 1979), who has been studying television, "TV reportage is different from newspaper reportage, since it is shown, heard and it requires a journalist, to be ready for any 
spontaneities." This certainly reminds us the pure aitys . As for the poetry, Knight argues, "Newspaper stories tell us about names and titles, distances and populations, fatality totals and investigations," he writes. (Knight, 2008) "Poems tell us about ourselves." For instance, Arman akhyn tells people about the Kazakh-Russian relationship, and language and cultural connections in the following ways:

Maskeuding shykhkhannan song törine biz,

Aitaiykh alkhaly yelge zhöndi lebiz.

Aitystyng osy yelde boluyna,

Dostyghy orys-kazakh boldy negiz.

Orys-Kazakh ezhelden tamyr bolghan,

Ol zhaily derekterdi mol bilemiz.

Orysty syilaghandykh osy yemes pe,

Putinning portretin törge ilemiz.

Kazakhstandykh kazakhtar bizder ushin,

Orys-Kazakh tilderi boldy yegiz.

Oryssha shuldirlesip özimizshe,

Shabymyz shart ketkenshe sögilemiz.

Kazakhsha tusinbeitin Kazakh khyzyn,

In the honored place of Moscow

Let's wish the people goodness.

Because this people came to this aitys,

Wishing the Russian-Kazakh friendship.

Russian-Kazakh have roots from long ago,

We know many favorable facts about it.

We respect Russians,

We also hang Putin's portrait in an honored place.

For us, Kazakhstani Kazakhs,

Russian and Kazakh languages are twins.

We speak Russian all the time,

It's as if we've made a contract,

If a Kazakh girl doesn't know Kazakh,

(Dubuisson, 2009)

Generally, the following common media functions can be applied to Journalism and aitys:

1. Various events, facts and situations are delivered to audience as information and news;

2. Serves to improve the outlook and knowledge of people educating them with cultural, historical and scientific definitions;

3. Shaping the social opinion and widening their mental horizons offering open discussions about communal, political, economic and other issues related to life experiences.

Dubuisson (2009) mentions that "The particular aitys genre of zhekpe-zhek (one-to-one, which he also refers to as simply shyndykh, truth) allows poets to speak openly because they can relay information about the political situation, "who is who and what is happening." As a result of aitys, he noted, people living in the country now have access to a lot of new information." Considering this point of view, it can be said, that aitys of those times functioned as today' s mass media (TV, radio) that could entertain people, informed them about the occurrence, taught mass on religion, ethics, and other norms. One of the famous akhyns Asiya Berkenova says that aitys serves to improve the public life. For example, according to her "Aitys played an important role during the policy of reviving Kazakh national traditions, celebrations, and names of Kazakh heroes" (Zhursin, 2012). Thorough analysis of the aytis' functions and its influences on audiences imply that it can definitely stand to be considered not only as a genre of folklore, but also as an old appearance of journalism. Knight (2008) writes, "What distinguishes poetry from journalism, aside from obvious distinctions of form - uses of words, patterns of words, sequences of words - is not a difference in kind but a difference in focus. Journalism is concerned with the look of the world; poetry with the feel of the world." The content of aitys always based on the circumstan ces, policies and many other conditions of nation.

The poets participating in aitys have equal rights and they are judged for their ability to evaluate locally happening events and stories authentically and truthfully for the benefit of the people. These poets are experienced people who understand the implications of such events on people's lives, whether positive or negative, and act as broadcasters who carry people's opinions to the wider public. Both poets describe, criticize and poetically 'discuss' the matter by creatively and cleverly putting it in verse, in a dialogical manner. It evolves in the following way: one starts his or her verse about a certain event or issue and gives his or her opinion on what is happening, and the second poet would then continue with his or her views of the same event, and carry on with other things. The poets analyze the implications of the event and speculate on the possible outcomes by bringing forward various arguments. The length of the competition depends on a mutual agreement between the public listening to them, the poets who participate, and the judges. The poet who manages to truthfully and critically analyze the social issues wins the aitys competition. In all, this competition was and still is a method of openly discussing what is happening in society and conveying critical views on events. The aitys is still used in Kazakhstan, but not as much as in the past. It is sort of an 'online' competition (as it is an unrehearsed event) between two poets designed to broadcast events analytically. Nowadays, online broadcasting has a similar effect of bringing the truth and gist of an event to the public. For instance, the live broadcasting of 
the national language abilities of the presidential candidates of the Republic of Kirgizstan was warmly welcomed, even by the neighbouring countries.

\subsection{The Skills of Critique}

Of course, the event and its resonance are not necessarily equal. The resonance of an event might be more or less powerful than the original event, depending on the context. In addition, an event might be regarded differently by different audiences for resonance is only the echo of an original happening.

In Kazakh oral philosophy there are several proverbs that carry a similar meaning to this last point. For instance, a Kazakh proverb that roughly translates as "hair is found where a horse has rolled, and a load of luggage is found where a camel has rolled (Note 1)" means that although there is evidence of what has happened, it is not as vivid as the reality. So one cannot judge the situation from a few pieces of evidence after it has happened. Another proverb, which literally translates as "sweet words make a snake come out of its nest, but harsh words make one give up one's religion", means that the way one treats the situation will define the consequences of it.

\subsection{Society and Journalism}

For example, the exclusive interview of the Euronews journalist John Davis with the then president of the Islamic Republic of Iran, Mahmoud Ahmadinejad from $9^{\text {th }}$ August, 2011 was repeatedly broadcast by Euronews. Why? Because the former head of Iran shared his views on the expansion of the West and the world regulation system that has been established since WW2. It is the journalist's skills of asking the right questions which made this interview so interesting and engaging. The main point here is that it is the art of asking questions that reveals the most engaging answers. The wording of the question is the key. More importantly, it is the journalists' ability of not taking for granted the foreign political views and the varied opinions he or she is surrounded with, for example, Giulietto Chiesa. Thankfully, in Kazakhstani journalism there exist skilled journalists who can deal with information candidly.

As part of the programme for increasing the use of the Kazakh language in the media, the TV programme called 'Protecting the language' hosted by Samal Meyramkyzy and Nazim Dawitalikyzy is an example of a fair judgment and unprecedented assessment of the language problems present in the country. This programme is evidence that Kazakhstani journalism is in line with current occurrences in the country and in my opinion, journalism flows with the processes happening in society. Journalism is developed and nurtured by those who respect and serve their country and advance their national values.

In the natural sciences there are objective and explicit answers. In the social sciences, where journalism belongs, the truth has many faces. Hard science is valued for its unbiased objective views, and hypotheses and theorems; however it is not sufficient for shaping the conscience of the nation. Journalism, in contrast, is a descriptive as well as inspirational and artistic concept that has the power to shape people's opinions and define truth. Therefore, it is necessary to establish new educational programmes in journalism by involving both theoretically and practically experienced journalists.

\section{Conclusion}

In sum, current Kazakhstani society has moved away from the times when people without a journalism degree or only those journalists educated in Russia worked in the area, which was common during the 1930s and 1940s. Even though there is plenty of room for improvement, it is a developing domain, full of potential. We would like to conclude with a quote on truth. "I believe in the existence of a great truth about freedom. Freedom has absolute primacy. I cannot accept what is imposed as the truth until I comprehend/behold it myself. I cannot recognize the truth as a lie, only because I am required to accept it as a lie. Actually nobody ever agreed on that" (Berdyaev, 2013:73).

\section{References}

Ahmetov, Sh., \& Yskakov, B. (1965). Aitys (Vol. 1). Almaty: Zhazushy.

Amandosov, T. (1978). Sovet Zhurnalistikasynyng teorijasy men praktikasy [Theory and practice of Sovet Journalism]. Almaty: Mektep

Amandosov, T. S. (1968). Kazak Sovet baspasozinin zhanrlary [Genres of Kazakh Soviet Press]. Almaty: Mektep

Auezov, M. (1991). Kazak adebietining tariryhy [History of literature]. Almaty: Ghylym.

Barmankulov, M. K. (1979). Zhurnalistika dlya vsekh: Obshnost i specifika zhanrov pechati, televideniya $i$ radioveshaniya [Journalism for everyone: General and specific genres of press, TV and Radio journalism]. 
Almaty: Kazakhtan.

Beljakova, L. (2013) Analiticheskaya jurnalistika v sisteme informacionnogo obespechenie inovacionniykh proektov. Minsk: Izdatel`ski centr Belarusskogo gosudarstvennogo universiteta

Berdyaev, N. A. (2013). Samopoznanie. [Self-Knowledge]. St. Petersburg: Azbuka.

Dubuisson, E -M. (2010). Confrontation in and through the Nation in Kazakh Aitys Poetry. Journalof Linguistic Anthropology, 20(1), 101-115. http://dx.doi.org/10.1111/j.1548-1395.2010.01051.x

Dubuisson, E -M. (2009). The value of a voice: Culture and critique in Kazakh aitys poetry (Unpublished doctoral dissertation). University of Michigan. USA. Retrieved from http://deepblue.lib.umich.edu/bitstream/handle/ 2027.42/64657/edubuiss_1.pdf?sequence $=1$

Kozhakeev, T. K. (2007). Tandamaly shygarmalar [Selected Essays]. Almaty: KazInfo.

Kunanbayev, A. K. (1961). Shygarmalarinin bir tomdik tolik zhinagi. [A Volume of Selected Stories]. Almaty, Kazakh National publishing house.

Khamzin, K. (2012). «Zhurnalistika negizderi» [Basics of Journalism]. Almaty: Kazakh universitety baspasy

Knight, B. (2008). Poetry and Journalism. IJPC Journal. Annenberg School for Communication \& Journalism, University of Southern California. Retrieved from http://www.ijpc.org/uploads/files/Poetry\%20and\% 20Journalism\%20Bill\%20Knight.pdf

Mamardashvili, M. K. (1991). O Filosofii. [About Philosophy]. Issues of Philosophy. Russian Academy of Sciences, Moscow: Nauka No.5, (pp. 3-25)

Willnat, L., Weaver, D. H., \& Choi, J. (2013). The global journalist in the twenty-first century. Journalism Practice, 7(2), 163-183. http://dx.doi.org/10.1080/17512786.2012.753210

Saudbayev, M., Bayimbetov, B., \& Karipov, B. (2014). Social Information Exchange in Aitys Performances. Paper was presented in 2nd World Conference on Design, Arts and Education DAE-2013 Bucharest, Romania. Retrieved from Procedia - Social and Behavioral Sciences 122 (pp. 72-76) http://dx.doi.org/10.1016/j.sbspro.2014.01.1305

Tertychnyi, A. A. (2010). Analiticheskaya jurnalistika [Alnalytical journalism]. Moscow: Aspect-Press.

Radlov, V. V. (1870). Obrazcy narodnoi literatury turkskih plemen, zhivushih v uzhnoi Sibiri iDzhungarskoi stepi (p. 45). S-Petersburg: Typography of Imperial Academy of Sciences.

Zholdasbekov, M. (2008). Khazakhqa allanyng bergen syiy edi. Egemen Kazakhstan, No. 4787

Zhursin, E. (Reporter). (2012, June 25). Alashtin arda oneri ajtis degen. Asyl khazyna. [Television series episode]. In Smayil,S (Producer), KazakhTV, Almaty, Kazakhstan: Khabar Agency. Retrieved from http://oldkazakh-tv.softdeco.net/kaz/asilkazina/archive/Alashtin_arda_oneri_ajtis_degen 1340617895 . html

\section{Note}

Note 1. Kazakhs historically were nomads, who moved from one place to another with herds of domestic animals such as horses, camels, and sheep, which is the reason having these particular examples with domestic animals. Horses were used for riding, whereas camels for transporting goods.

\section{Copyrights}

Copyright for this article is retained by the author(s), with first publication rights granted to the journal.

This is an open-access article distributed under the terms and conditions of the Creative Commons Attribution license (http://creativecommons.org/licenses/by/3.0/). 